\title{
The demographic factors that make Islam the world's fastest-growing major religious group
}

\author{
CONRAD HACKETT and MICHAEL LIPKA
}

mong the world's major religious groups, Muslims have the lowest median age and the highest Afertility rates. Due to these demographic factors, Muslims are expected to increase in number faster than any other major group in the period between 2015 and 2060, growing at more than twice the pace of global population growth.

In the next half century or so, Christianity's long reign as the world's largest religion may come to an end, according to a new report (Hackett et al. 2017) that builds on Pew Research Center's original population growth projections for religious groups (Hackett et al. 20 I 5). Indeed, Muslim populations will grow more than twice as fast as the overall world population between 2015 and 2060 and, in the second half of this century, will likely surpass Christians as the world's largest religious group.

While the world's population is projected to grow 32 per cent in the coming decades, the number of Muslims is expected to increase by 70 per cent - from I. 8 billion in

\section{Muslims projected to be fastest- growing major religious group}

Estimated percent change in population size, 2015-2060

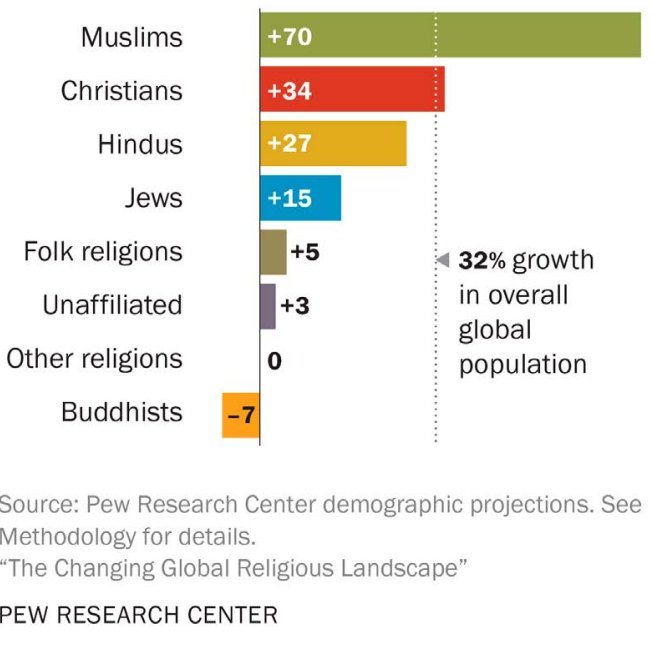

Fig. 1. 2015 to nearly 3 billion in 2060. In 2015, Muslims made up 24. I per cent of the global population. Forty-five years later, they are expected to make up more than three-in-ten of the world's people (3 I.I \%). 


\section{Muslim and non-Muslim fertility rates, by region, 2015-2020}

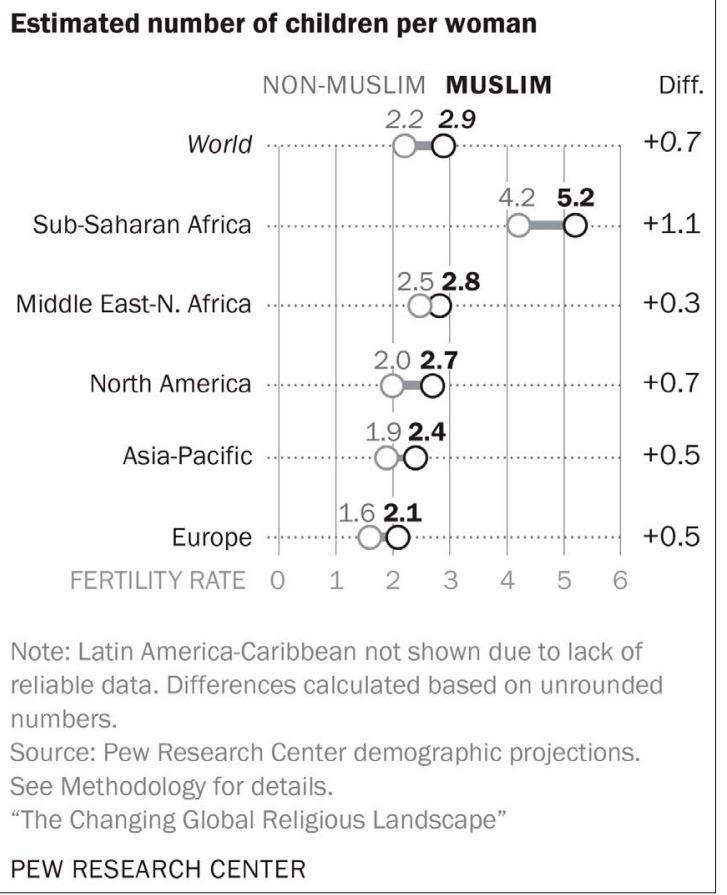

Fig. 2.
The main reasons for Islam's growth ultimately involve simple demographics. To begin with, Muslims have more children than members of the seven other major religious groups analysed in the study. Muslim women have an average of 2.9 children, significantly higher than the next-highest group (Christians at 2.6) and the average of all non-Muslims (2.2).In all major regions where there is a sizeable Muslim population, Muslim fertility exceeds nonMuslim fertility.

The growth of the Muslim population also is helped by the fact that Muslims have the youngest median age ( 24 in 2015) of all major religious groups, more than seven years younger than the median age of non-Muslims (32).

A greater proportion of Muslims will soon be at the point in their lives when people begin having children. This, combined with high fertility rates, will accelerate Muslim population growth.

More than a third of Muslims are concentrated in Africa and the Middle East, regions that are projected to have the biggest population increases. But even within these high-growth regions - as well as others - Muslim populations are projected to grow faster than members of other groups. For example, Muslims in sub-Saharan Africa, on average, are younger and have a higher fertility rate than the overall population of the region. In fact, Muslim populations are expected to grow as a percentage of every region except Latin America and the Caribbean, where relatively few Muslims live.

The same dynamics hold true in many countries where Muslims live in large numbers alongside other religious groups. For example, the number of Muslims in India is growing at a faster rate than the country's majority 
Hindu population, and is projected to rise from 14.9 per cent of India's 2015 population to 19.4 per cent (or 333 million people) in 2060. And while there were similar numbers of Muslims and Christians in Nigeria as of 2015, Muslims have higher fertility rates there and are expected to grow to a solid majority of Nigeria's population (60.5\%) in 2060.

Meanwhile, religious switching - which is expected to hinder the growth of Christians by an estimated 72 million between 2015 and 2060 - is not expected to have a negative net impact on Muslim population growth.

\section{Muslim and non-Muslim median age, by region, 2015}

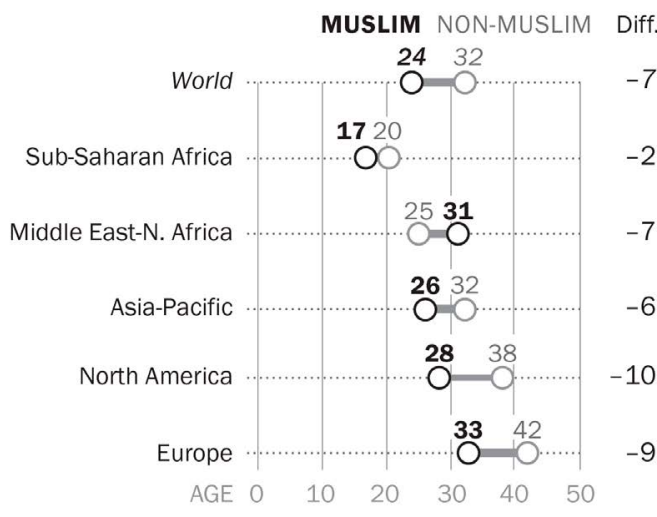

Note: Latin America-Caribbean not shown due to lack of reliable data. Differences calculated based on unrounded numbers.

Source: Pew Research Center demographic projections. See Methodology for details.

"The Changing Global Religious Landscape"

\section{PEW RESEARCH CENTER}

\section{Conrad Hackett is associate director of research and senior demographer at Pew Research Center. His} expertise is in international religious demography, sociology of religion, and how religion relates to characteristics including gender, fertility and education. He is an author of The Future of World Religions: Population Growth Projections, 2010-2050 (Pew Research Center 2015), Religion and Education Around the World (Pew Research Center 2016), The Global Religious Landscape (Pew Research Center 2012), The Gender Gap in Religion Around the World (Pew Research Center 2016), Global Christianity (Pew Research Center 2011), The Global Catholic Population (Pew Research Center 2013) and various other studies of religious demography. He is frequently interviewed about global religion trends by media outlets such as BBC, CNN, Deutsche Welle, NPR, MSNBC, the Financial Times, The New York Times and The Wall Street Journal.

Michael Lipka is a senior editor focusing on religion at Pew Research Center, where he regularly writes about public opinion in the United States and internationally as well as demographic research on topics related to secularization and religious change. Lipka specializes in finding new and innovative ways to explain quantitative research findings to informed audiences. He has served as a primary editor on recent reports about Muslims in America (Pew Research Center, 26.7.2017), Muslims in Europe (Pew Research Center, 29.11.2017), global religious demography (Pew Research Center, 5.4.2017), religious 
divisions in Israel (Pew Research Center, 8.3.2016), and religion and politics across Central and Eastern Europe (Pew Research Center, 10.5.2017), and has written more than 100 blog posts about Pew Research Center findings.

\section{References}

Hackett, Conrad, Phillip Connor, Marcin Stonawski, Vegard Skirbekk, Michaela Potančoková, and Guy Abel, 20 I 5. The Future of World Religions: Population Growth Projections, 2010-2050 (Pew Research Center), <http://www. pewforum.org/201 5/04/02/religious-projections-2010-2050/> (accessed 22.8.2017)

Hackett, Conrad, Marcin Stonawski, Michaela Potančoková, Vegard Skirbekk, Phillip Connor, David McClendon, and Stephanie Kramer, 2017. The Changing Global Religious Landscape (Pew Research Center), <http://www. pewforum.org/2017/04/05/the-changing-global-religious-landscape/> (accessed 22.8.2017) 